\title{
NUCLEAR CHANGES IN FLAX
}

\author{
G. M. EVANS \\ Department of Agricultural Botany, University College of Wales, Aberystwyth
}

Received 28.ii.67

\section{INTRODUGTION}

Heritable changes are induced by specific environmental conditions in the flax variety Stormont Cirrus (Durrant, 1962). Plants of the original variety (plastic genotroph) can be changed into a large stable genotroph $(L)$ or into a small stable genotroph $(S)$ by growing the plants in soils of high nitrogen and high phosphorus respectively, together with suitable soil fertility, temperature, daylength and light intensity. The large and small genotrophs have remained stable for 10 generations, $L$ being more than six times the weight of $S$. Genetical studies have shown that they behave as two distinct genetic types giving equilinear inheritance when they are crossed and there is no transmission through reciprocal grafts, suggesting that the nucleus and its chromosomes are probably involved in the genotrophic change. So far it has been impossible to carry out detailed karyotype analysis of the somatic chromosomes because of their very small size. Studies were therefore made to determine whether any nuclear changes could be detected directly by cytochemical means. Attention was paid mainly to quantitative variation in nuclear DNA between the flax genotrophs.

\section{(a) Feulgen photometry}

\section{EXPERIMENTAL TEGHNiQues}

Feulgen photometry is now extensively used to estimate relative amounts of DNA in individual nuclei (Leutchenberger, 1954; Swift, 1955; Vendrely and Vendrely, 1956; Waker, 1959; McLeish, 1961). The validity of this method has been well established by comparisons between estimations of Feulgen stain values with chemically determined estimates of DNA in the same material (Deeley, Davies and Chayen, 1957; Ris and Mirsky, 1949; Leuchtenberger, 1954; McLeish and Sunderland, 1961).

Root meristems of Linum have proved difficult to stain by the Feulgen technique. The root cells have a very thick cell wall and the cytoplasm has a very high oil content, and these could quite feasibly interfere with penetration of either the fixative or the stain. Even so, pre-treatment with pectinase, and cellulase and the use of fat solvent fixatives did not improve the staining. Consequently a staining technique was devised using the apical shoot meristems.

Plants were grown in compost with John Innes No. 1 fertiliser in shallow boxes which were kept in a heated greenhouse in winter but placed outside in summer. All plants in any one experiment were grown under exactly the same conditions.

\section{Fixation}

Shoot apices were taken from seedling plants 2-3 in. high, and as many leaves as possible were removed immediately before fixation in 
4 per cent. formaldehyde in phosphate buffer for 2 hours $(p \mathrm{H} \mathrm{7 \cdot 0)}$ (McLeish and Sunderland, 1961).

A thorough washing for 24 hours is necessary following formaldehyde fixation, and during this time the remaining small leaves surrounding the apical meristem were removed under low magnification.

\section{Hydrolysis}

It was suggested by Swift (1955) that the optimum hydrolysis time for maximum staining might vary between different species, although McLeish (1961) found that a hydrolysis time of $12 \mathrm{~min}$. at $60^{\circ} \mathrm{C}$. using $\mathrm{N} \mathrm{HCl}$

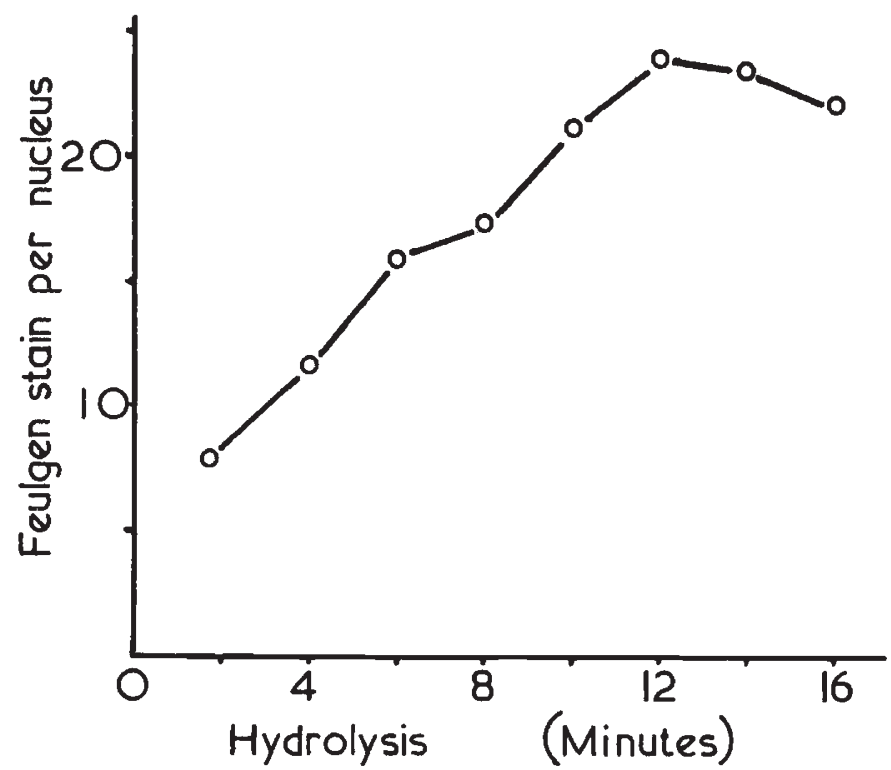

Fig. 1.-The amount of Feulgen stain per nucleus obtained after various periods of hydrolysis at $60^{\circ} \mathrm{C}$. in $\mathrm{N} \mathrm{HCl}$.

following formaldehyde fixation gave maximum staining in all the species he studied. Nevertheless, as a check, apical shoot meristems of the $L$ genotroph were hydrolysed for different lengths of time in $\mathrm{N} \mathrm{HCl}$ at $60^{\circ} \mathrm{C}$. and stained in Feulgen reagent at $20^{\circ} \mathrm{C}$. for 2 hours. The absorption of five separate $4 \mathrm{C}$ nuclei were then measured for each hydrolysis time (fig. 1). Maximum staining was obtained after 12 minutes' hydrolysis, as McLeish found for the ten species he studied. Consequently, a standard 12 minutes' hydrolysis time was used for all further estimations.

\section{Staining and preparation of squashes}

Following hydrolysis the apices were rinsed in distilled water and stained in Feulgen reagent of $p \mathrm{H} 3.6$ for 2 hours at $20^{\circ} \mathrm{C}$. This was followed by three washings of $15 \mathrm{~min}$. each in $\mathrm{SO}_{2}$ water and finally a rinse in distilled water. A small segment of the shoot apex was macerated in glycerol on thin slides and finally covered with a strip of Melinex (obtained from I.C.I. Plastic Division). 


\section{Photometric measurements}

The amount of Feulgen stain per nucleus and, by inference, the amount of DNA was measured using light of $560 \mathrm{~m} \mu$ by means of a Barr and Stroud integrating microdensitometer fitted with a crushing condenser to flatten the object.

\section{(b) Isolation of nuclei}

McLeish (1963) observed that root-tip nuclei could easily be isolated by crushing root tips which had been previously fixed in cold dilute formaldehyde solution. He suggested that this technique could be adapted for extracting nuclei from a single root tip on an ordinary glass slide. Radicle tips of germinating flax seeds were fixed for $25 \mathrm{~min}$. in 1.0 per cent. formaldehyde in $\frac{M}{30}$ phosphate buffer kept at $2^{\circ} \mathrm{C}$. Concentration of formaldehyde and length of fixation are critical for isolation of flax nuclei.

The tip was then macerated with a glass tapper on a previously cooled slide. Most of the debris can be removed and a cover glass placed in position. A good yield of isolated nuclei free of cytoplasm can be obtained by this method. The slide is allowed to dry out slightly for about $5 \mathrm{~min}$. and the cover glass floated off by inverting the slide in a shallow trough of 2 per cent. formaldehyde in which it is allowed to stand for a further $30 \mathrm{~min}$. to complete fixation. Enough nuclei adhere to the glass slide after a thorough washing for hydrolysis and staining to be carried out as described for the squash preparation. Finally, a drop of glycerol and a square of melinex were placed in position to cover the smear of isolated nuclei.

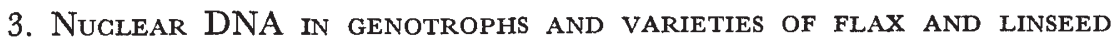

Preliminary results showed a difference in mean Feulgen stain per nucleus between the $L$ and $S$ genotrophs of the flax variety Stormont Cirrus. Consequently, Feulgen stain measurements were made on nuclei in shoot apices of the large, the plastic and the small genotrophs of both Stormont Cirrus and Lyral Prince (another flax variety in which heritable changes had been induced) together with eight commercial varieties of flax and two of linseed which had been grown under field conditions for many generations (tables 1 and 2). There were four replicates and each replicate contained one plant of each of the 16 types. One slide was prepared from each plant and ten $4 \mathrm{C}$ nuclei, some of which were well-squashed metaphases, were measured per slide. The replicates contained different plants and were fixed and stained separately. All the plants had been grown outside during May and early June.

The large genotroph of both Stormont Cirrus and Lyral Prince has more nuclear DNA than the corresponding small genotrophs, the plastic genotrophs being intermediate in both cases. These differences are highly significant as shown by the genotrophs item in table 2. There are no significant overall differences between the various commercial varieties of flax although there is some difference between the two linseed varieties, Dakota having significantly $(\mathrm{P}<1$ per cent.) more DNA per nucleus than Royal, and over all between the flax and linseed varieties $(\mathrm{P}<2$ per cent.). These results imply that the environments which produced genotrophic changes also caused changes in the nuclear DNA as measured by Feulgen photometry 
TABLE 1

DNA values in arbitrary units of $4 C$ nuclei of genotrophs and commercial varieties of flax and linseed

\begin{tabular}{|c|c|c|c|c|}
\hline \multicolumn{4}{|c|}{ Replicates } & \multirow[b]{2}{*}{ Total } \\
\hline 1 & 2 & 3 & 4 & \\
\hline $21 \cdot 4$ & $21 \cdot 5$ & $21 \cdot 4$ & $21 \cdot 5$ & $85 \cdot 80$ \\
\hline $23 \cdot 75$ & $23 \cdot 8$ & $23 \cdot 6$ & $22 \cdot 5$ & $93 \cdot 6$ \\
\hline $19 \cdot 4$ & $20 \cdot 8$ & $20 \cdot 0$ & $20 \cdot 25$ & $80 \cdot 45$ \\
\hline $22 \cdot 3$ & $22 \cdot 55$ & $22 \cdot 95$ & $22 \cdot 65$ & $90 \cdot 4$ \\
\hline $24 \cdot 1$ & $23 \cdot 25$ & $24 \cdot 65$ & $23 \cdot 3$ & $95 \cdot 30$ \\
\hline $21 \cdot 4$ & $22 \cdot 1$ & $21 \cdot 4$ & $21 \cdot 4$ & $86 \cdot 30$ \\
\hline
\end{tabular}

Flax varieties

$\begin{array}{llllll}\text { Percello } & 23 \cdot 05 & 22 \cdot 9 & 22 \cdot 1 & 23 \cdot 2 & 91 \cdot 25 \\ \text { Lyral Monarch } & 23 \cdot 2 & 21 \cdot 15 & 22 \cdot 7 & 21 \cdot 45 & 88 \cdot 50 \\ \text { Stormont Gossomer } & 24 \cdot 05 & 20 \cdot 8 & 21 \cdot 9 & 21 \cdot 5 & 88 \cdot 25 \\ \text { Hollandia } & 22 \cdot 1 & 21 \cdot 8 & 21 \cdot 7 & 22 \cdot 3 & 87 \cdot 90 \\ \text { Stormont Motley } & 23 \cdot 7 & 22 \cdot 0 & 20 \cdot 8 & 21 \cdot 2 & 87 \cdot 70 \\ \text { Rembrandt } & 22 \cdot 1 & 22 \cdot 0 & 20 \cdot 9 & 22 \cdot 0 & 87 \cdot 00 \\ \text { Norfolk Princess } & 20 \cdot 9 & 20 \cdot 6 & 22 \cdot 9 & 22 \cdot 1 & 86 \cdot 50 \\ \text { Mandarin } & 22 \cdot 2 & 20 \cdot 9 & 21 \cdot 6 & 20 \cdot 55 & 85 \cdot 25 \\ & & & & & \\ \text { inseed varieties } & & & & & \\ \text { Dakota } & 24 \cdot 8 & 23 \cdot 1 & 23 \cdot 2 & 23 \cdot 2 & 94 \cdot 30 \\ \text { Royal } & 23 \cdot 0 & 21 \cdot 8 & 21 \cdot 6 & 21 \cdot 2 & 87 \cdot 60\end{array}$

TABle 2

Analysis of variance of nuclear DNA of varieties and genotrophs of flax and linseed

\begin{tabular}{|c|c|c|c|c|}
\hline Item & d.f. & Mean square & Variance ratio & Probability \\
\hline Replicates & 3 & $1 \cdot 630$ & $3 \cdot 098$ & $0 \cdot 05$ \\
\hline Genos (genotrophs + genotypes) & 15 & $3 \cdot 556$ & $6 \cdot 760$ & $<0 \cdot 001$ \\
\hline Genotroph & 5 & $7 \cdot 668$ & $14 \cdot 577$ & $<0.001$ \\
\hline $\begin{array}{l}L, S, P l \text { genotrophs } \\
\text { Genotypes } \\
\text { Genotype/genotroph }\end{array}$ & $\begin{array}{l}2 \\
1 \\
2\end{array}$ & $\begin{array}{l}15 \cdot 510 \\
6 \cdot 15 \\
0 \cdot 585\end{array}$ & $\begin{array}{l}29 \cdot 486 \\
11 \cdot 69 \\
1 \cdot 112\end{array}$ & $\begin{array}{c}<0.001 \\
<0.01 \\
\text { N.S. }\end{array}$ \\
\hline \multicolumn{5}{|l|}{ Varieties } \\
\hline $\begin{array}{l}\text { Flax } \\
\text { Linseed }\end{array}$ & $\begin{array}{l}7 \\
1\end{array}$ & $\begin{array}{l}0 \cdot 767 \\
5 \cdot 61\end{array}$ & $\begin{array}{r}1 \cdot 458 \\
10 \cdot 665\end{array}$ & $\begin{array}{l}\text { N.S. } \\
<0.01\end{array}$ \\
\hline Error & 45 & $0 \cdot 526$ & - & 一 \\
\hline Flax v. linseed & - & $\begin{aligned} \mathrm{VD} & =3.98 \\
\mathrm{Ve} & =1.372\end{aligned}$ & $t=2 \cdot 905$ & $0 \cdot 02$ \\
\hline
\end{tabular}


in both Stormont Cirrus and Lyral Prince, the differences being larger than those between the other flax varieties. Although the above estimations were made under identical conditions of fixing hydrolysis and staining, cytoplasmic or cell wall differences between the morphologically different tissues of the genotrophs could conceivably alter the rate of penetration of the acid or stain or even alter the $p H$ of the stain. Further tests were therefore carried out on the $L$ and $S$ genotrophs of Stormont Cirrus.

\section{DNA estimations on isolated nuclei}

Photometric measurements were made on Feulgen-stained isolated nuclei of both the $L$ and $S$ genotroph of Stormont Cirrus in order to find out whether the cell wall and cytoplasm had any quantitative effect on the

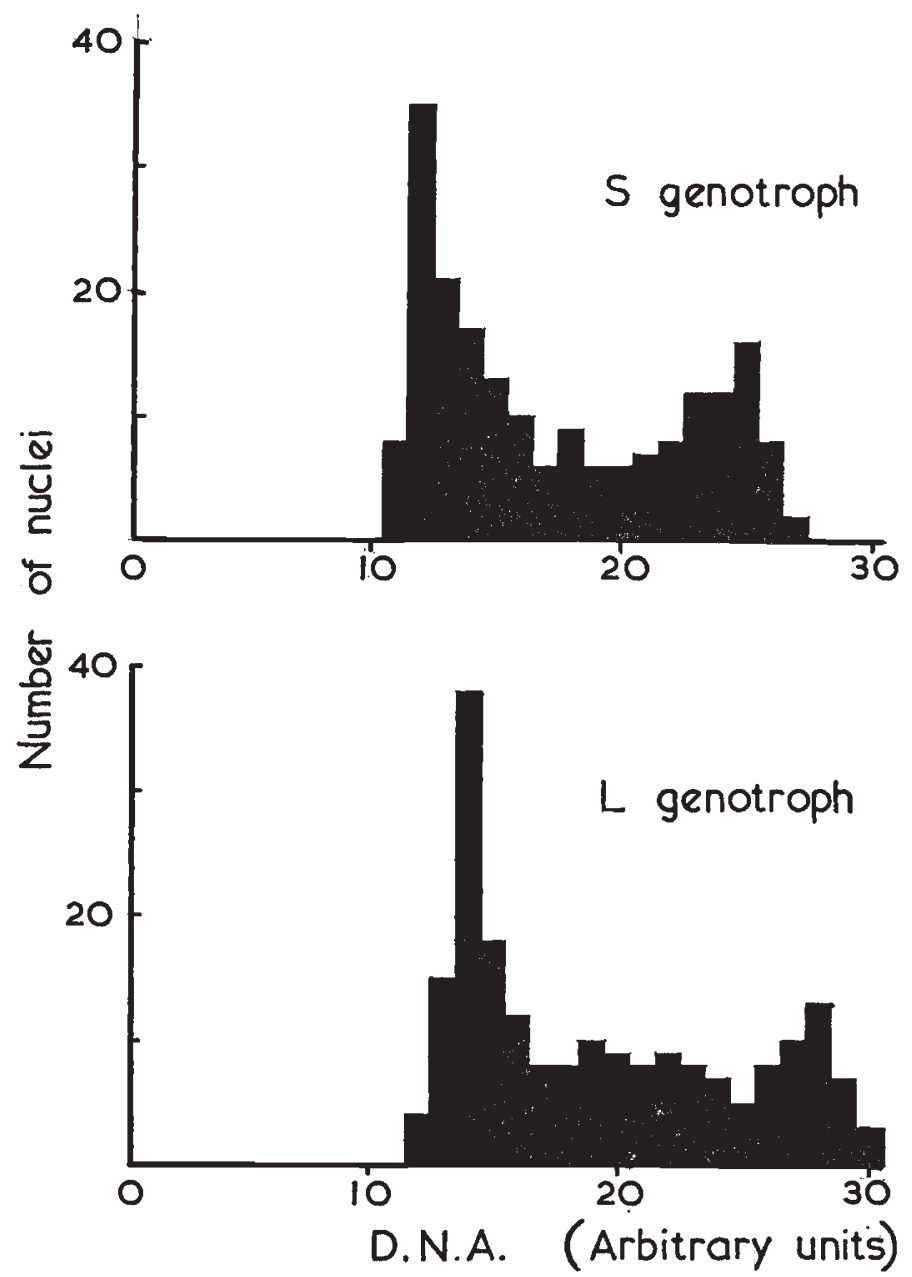

Fig. 2.-Histograms of the distribution of DNA values obtained by measuring the amount of Feulgen stain in isolated nuclei of the large and small genotrophs of Stormont Cirrus.

degree of staining. As it was very difficult to pick out $4 \mathrm{C}$ nuclei from other interphase nuclei in these preparations, a random sample of 50 nuclei per slide were measured (fig. 2). The frequency of occurrence of particular 
Feulgen values per nucleus are plotted for both $L$ and $S$ genotrophs, the four replicates having been pooled together. A bimodal distribution of Feulgen values is obtained in both genotrophs the lower mode being the $2 \mathrm{C}$ value and the higher mode the $4 \mathrm{C}$ value. However, both the $2 \mathrm{C}$ and the $4 \mathrm{C}$ modes are higher in the $L$ genotroph than in the $S$ and this is consistent with the results obtained from squash preparations where the 4C DNA value was 16 per cent. higher in the $L$ genotroph. This shows that the difference in Feulgen stain per nucleus is not due to any difference in penetration of either the fixative or of the reagents used for staining.

\section{Possible effects of different rates of metabolic turnover}

Under similar growing conditions the $L$ genotroph has a higher growth rate than the $S$ genotroph and it is therefore reasonable to assume that the rate of metabolic turnover is different. In order to find out whether this

TABLE 3

Nuclear DNA values in arbitrary units of the $\mathbf{L}$ and $\mathrm{S}$ genotrophs grown in two soils and two temperature regimes

\begin{tabular}{clcc} 
Genotroph & \multicolumn{1}{c}{ Soil } & Temperature & $\begin{array}{c}\text { DNA values } \\
\text { in arbitrary units }\end{array}$ \\
$L$ & J.I. & High & $26 \cdot 83$ \\
& J.I. & Low & $26 \cdot 75$ \\
& Poor soil & High & $27 \cdot 45$ \\
& Poor soil & Low & $26 \cdot 85$ \\
$S$ & & High & $23 \cdot 18$ \\
& J.I. & Low & $21 \cdot 68$ \\
& J.I. & High & 22.75 \\
& Poor soil & Low & 23.48
\end{tabular}

Analysis of variance

\begin{tabular}{|c|c|c|c|c|}
\hline Item & d.f. & Mean square & Variance ratio & Probability \\
\hline Treatment & 7 & $10 \cdot 70$ & - & - \\
\hline$L-S$ & 1 & $70 \cdot 56$ & $61 \cdot 894$ & $<0.1 \%$ \\
\hline J. I.-Poor Soil & 1 & $1 \cdot 10$ & - & - \\
\hline High-low temp. & 1 & 0.53 & - & - \\
\hline Genotroph/soil & 1 & $0 \cdot 11$ & - & - \\
\hline Genotroph/temp. & 1 & 0.003 & - & - \\
\hline Soil temp. & 1 & $0 \cdot 172$ & 一 & - \\
\hline Gen./soil/temp. & 1 & 1.76 & $1 \cdot 543$ & 一 \\
\hline Replicate & 1 & $1 \cdot 75$ & 1.535 & 一 \\
\hline Error & 7 & $1 \cdot 14$ & - & - \\
\hline Total & 15 & 一 & - & - \\
\hline
\end{tabular}

alone could be responsible for the different nuclear DNA values obtained, different growth rates over and above that shown by the genotrophs were simulated by growing seedlings of both genotrophs in two different soils at two different temperatures and the amount of Feulgen stain per $4 \mathrm{C}$ nucleus measured in squash preparations (table 3 ). The highly significant difference in nuclear DNA between the $L$ and $S$ genotrophs is still evident whereas the 
simulated growth rates have no effect in themselves nor have any significant influence on the genotrophic difference. Since one of the soils involved was of very low fertility with an obvious deficiency in several nutrients, it is also apparent that the level of various nutrients has little effect on the degree of staining at least under these conditions of temperature and daylength.

\section{NuGlear DRY MASS AND NUGLEAR VOLUME OF LARGE AND SMALl Genotrophs of Stormont Cirrus}

A parallel difference in nuclear dry mass and nuclear size would be expected as a consequence of this variation in nuclear DNA.

Estimations of the dry mass of individual nuclei were calculated from data obtained using interferometry and using the equation of Barer (1952).

$$
\text { Dry Mass }=\frac{\text { Optical path. difference } \times \text { Area }}{X} \text {. }
$$

Nuclei were isolated from root tips of both $L$ and $S$ genotrophs of Stormont Cirrus. Optical path differences were measured in monochromatic light of $543 \mathrm{~m} \mu$ using the Smith half-shade eyepiece attachment on a Baker

TABLE 4

Dry mass of 4 C nuclei $\left(\mathrm{gm} . \times 10^{-11}\right)$

$\begin{array}{lcc} & \text { Large } & \text { Small } \\ 1 & 3 \cdot 14 & 2 \cdot 61 \\ 2 & 3 \cdot 79 & 2 \cdot 78 \\ 3 & 3 \cdot 88 & 3.01 \\ 4 & 3 \cdot 63 & 2 \cdot 86 \\ 5 & 3.26 & 2 \cdot 86 \\ 6 & 3 \cdot 43 & 2 \cdot 85 \\ \text { Overall mean } & 3.52 & 2 \cdot 83 \\ & \mathbf{P}=<0.1 \text { per cent. }\end{array}$

Each value is the mean of the five highest values of ten large nuclei measured per slide.

interference microscope. The areas were calculated from measurements of the longest and shortest diameters as obtained by using a screw micrometer eyepiece. A value of 0.18 was used for $X$ as this is the constant generally used for proteins and nucleoproteins. All measurements were made on nuclei mounted in dilute phosphate buffer to prevent increase in size which occurs when isolated nuclei are mounted in water. Although the equation given above is intended for objects mounted in water, the difference in refractive index of $\frac{M}{30}$ phosphate buffer and pure water is so small as to make very little difference to the calculations (McLeish, 1963). Optical path difference and area measurements were obtained separately for both nucleolus and the remainder of each nucleus and the data summed to give a total dry mass per nucleus.

Data presented in table 4 give the mean dry mass of $4 \mathrm{C}$ nuclei from six radicles of both genotrophs. The difference between the values for the two genotrophs is highly significant $(P=<0.1$ per cent.) and this difference in mass closely parallels the difference in DNA described earlier. 
Nuclear volume as calculated from measurements of 4G nuclei in longitudinal sections also show very similar variation (table 5), the nuclei of the $L$ genotroph having a mean volume greater by almost 17 per cent. than those of the $S$ genotroph.

TABLE 5

Nuclear volume of $4 C$ nuclei $\left(\mu^{3}\right)$

$\begin{array}{lcc} & \text { Large } & \text { Small } \\ 1 & 57 \cdot 263 & 45.978 \\ 2 & 56 \cdot 571 & 46 \cdot 664 \\ 3 & 50 \cdot 264 & 45 \cdot 114 \\ 4 & 58 \cdot 081 & 49 \cdot 217 \\ 5 & 56 \cdot 784 & 51 \cdot 996 \\ \text { Overall mean } & 55 \cdot 793 & 47.794 \\ & & \end{array}$

\section{NuGlear DNA in EPITROPHS AND GENOTROPHS}

A major characteristic of the $\mathrm{F}_{1}$ 's of a cross between $L$ and $S$ genotrophs is the increased variation in phenotypic characters such as plant weight. This variation is inherited in $\mathrm{F}_{2}$ 's and subsequent generations resulting in a range of types termed epitrophs varying in size from large to small (Durrant, 1962). It was shown above that changes in phenotype associated with genotrophic change were also correlated with changes in nuclear DNA. Further confirmation of this correlation was obtained from an analysis of the derivatives of a cross between a white flowered mutant $\left(L^{w}\right)$ of the large genotroph and the normal small genotroph. Phenotypic selection for large and small plants (epitrophs) had been carried out from the $F_{1}$ to the $F_{4}$ generations and estimates of nuclear DNA made on $\mathrm{F}_{5}$ plants of both white and blue flowered selection lines together with the $L, L^{w}$ and $S$ genotrophs. Nuclear DNA were measured in two $F_{5}$ progeny plants from each of three $\mathrm{F}_{4}$ plants of each epitroph line, a similar pattern being used for the genotrophs for comparative purposes (tables 6 and 7). The difference between large and small genotrophs is highly significant and consistent with previous results; the nuclear DNA value of the large white genotroph is as expected almost identical to that of the large blue genotroph from which it was originally derived. Among the epitrophs the high plant weight selection lines have more DNA than the low selection lines although the differences are not as great as those between the genotrophs and are not significant when tested against the between families mean square. On the other hand the between family mean square is significantly greater than the within family mean square and both of these are significantly greater than the respective items in the genotroph analysis, V.R. $=5.05, \mathrm{P}<0.05$ for between families, and V.R. $=3.61, P<0.05$ for within families, which shows that in the $F_{4}$ and $F_{5}$ generations there still remains a large amount of genetic variation within the selection lines which presumably is utilisable for further progress in selection. Although significance is not obtained the DNA differences are in the expected directions and they were closely correlated with observations on plant size. 
The lack of significance in DNA content between the large and small selections lines is largely due to the blue epitroph selections wherein the progeny of one $\mathrm{F}_{4}$ plant gives an exceptionally low value. These selections were re-examined in the $\mathrm{F}_{6}$ where the difference in nuclear DNA between the large and small blue flowered selection lines was significant $(P=<0.01)$.

TABLE 6

Nuclear DNA values. The three columns contain the progeny of the three respective $F_{4}$ plants

\begin{tabular}{|c|c|c|c|c|c|c|}
\hline Types & & 1 & 2 & 3 & Total & Mean \\
\hline \multicolumn{7}{|l|}{ Genotrophs } \\
\hline Large & $\begin{array}{l}S 1 \\
S 2\end{array}$ & $\begin{array}{l}26 \cdot 90 \\
27 \cdot 75\end{array}$ & $\begin{array}{l}28 \cdot 30 \\
29 \cdot 10\end{array}$ & $\begin{array}{l}28 \cdot 95 \\
28 \cdot 10\end{array}$ & $\left.\begin{array}{l}84 \cdot 15 \\
84 \cdot 95\end{array}\right\}$ & $169 \cdot 10$ \\
\hline Small & $\begin{array}{l}S 1 \\
S 2\end{array}$ & $\begin{array}{l}23 \cdot 25 \\
25 \cdot 00\end{array}$ & $\begin{array}{l}25 \cdot 15 \\
25 \cdot 45\end{array}$ & $\begin{array}{l}25 \cdot 70 \\
25 \cdot 85\end{array}$ & $\left.\begin{array}{l}74 \cdot 10 \\
76 \cdot 30\end{array}\right\}$ & $150 \cdot 40$ \\
\hline Large white & $\begin{array}{l}S 1 \\
S 2\end{array}$ & $\begin{array}{l}28 \cdot 10 \\
28 \cdot 85\end{array}$ & $\begin{array}{l}28 \cdot 75 \\
28 \cdot 00\end{array}$ & $\begin{array}{l}28 \cdot 30 \\
29 \cdot 10\end{array}$ & $\left.\begin{array}{l}85 \cdot 15 \\
85 \cdot 95\end{array}\right\}$ & $171 \cdot 10$ \\
\hline \multicolumn{7}{|l|}{ Epitrophs } \\
\hline Small white & $\begin{array}{l}S 1 \\
S 2\end{array}$ & $\begin{array}{l}24 \cdot 10 \\
25 \cdot 35\end{array}$ & $\begin{array}{l}24 \cdot 90 \\
26 \cdot 70\end{array}$ & $\begin{array}{l}26 \cdot 80 \\
25 \cdot 50\end{array}$ & $\left.\begin{array}{l}75 \cdot 80 \\
77 \cdot 55\end{array}\right\}$ & $153 \cdot 35$ \\
\hline Large white & $\begin{array}{l}S 1 \\
S 2\end{array}$ & $\begin{array}{l}27 \cdot 30 \\
28 \cdot 15\end{array}$ & $\begin{array}{l}25 \cdot 30 \\
26 \cdot 90\end{array}$ & $\begin{array}{l}28 \cdot 70 \\
28 \cdot 40\end{array}$ & $\left.\begin{array}{l}81 \cdot 30 \\
83 \cdot 45\end{array}\right\}$ & $164 \cdot 75$ \\
\hline Small blue & $\begin{array}{l}S 1 \\
S 2\end{array}$ & $\begin{array}{l}23 \cdot 75 \\
25 \cdot 25\end{array}$ & $\begin{array}{l}25 \cdot 55 \\
25 \cdot 50\end{array}$ & $\begin{array}{l}25 \cdot 80 \\
25 \cdot 60\end{array}$ & $\left.\begin{array}{l}75 \cdot 10 \\
76 \cdot 35\end{array}\right\}$ & $151 \cdot 45$ \\
\hline Large blue & $\begin{array}{l}S 1 \\
S 2\end{array}$ & $\begin{array}{l}25 \cdot 80 \\
27 \cdot 35\end{array}$ & $\begin{array}{l}29 \cdot 50 \\
26 \cdot 50\end{array}$ & $\begin{array}{l}22 \cdot 75 \\
23 \cdot 50\end{array}$ & $\left.\begin{array}{l}78 \cdot 05 \\
77 \cdot 35\end{array}\right\}$ & $155 \cdot 40$ \\
\hline
\end{tabular}

TABLE 7

Analysis of variance of nuclear DNA of progeny of $F_{4}$ families

Item d.f. Mean square Variance ratio Probability

\begin{tabular}{|c|c|c|c|c|}
\hline \multicolumn{5}{|l|}{ Genotrophs } \\
\hline Series & 1 & $0 \cdot 8$ & - & - \\
\hline Genotroph & 2 & $21 \cdot 7$ & $25 \cdot 0$ & $<0.001$ \\
\hline $\begin{array}{l}\text { Between } \mathrm{F}_{4} \text { families within } \\
\text { genotype }\end{array}$ & 6 & 0.9 & $2 \cdot 5$ & - \\
\hline Within $\mathrm{F}_{4}$ families & 8 & $0 \cdot 3$ & - & - \\
\hline \multicolumn{5}{|l|}{ Epitrophs } \\
\hline Series & 1 & $0 \cdot 8$ & - & - \\
\hline Epitrophs & 3 & $5 \cdot 8$ & $1 \cdot 3$ & - \\
\hline $\begin{array}{l}\text { Between } \mathrm{F}_{4} \text { families within } \\
\text { epitrophs }\end{array}$ & 8 & $4 \cdot 4$ & $4 \cdot 4$ & $<0.05$ \\
\hline Within $\mathrm{F}_{4}$ families & 11 & $1 \cdot 0$ & 一 & - \\
\hline
\end{tabular}

\section{Time of NUGlear GHANGE}

Previous observations by Durrant indicated that the genotrophic change could only be induced by giving the appropriate environmental and edaphic conditions during the first 5 or 6 weeks of growth. This in itself was not conclusive evidence that these changes were completed during this time as it is possible that some physiological condition might have been produced 
that would manifest itself later in some form of nuclear change during gametogenesis.

In order to determine whether any nuclear change did occur during the first weeks of growth, seeds of the plastic genotroph were sown in soils of contrasting nutrient composition in a heated greenhouse with a daylength of approximately 14 hours with the object of inducing changes to the $L$ and $S$ type. High nitrogen was added to induce the $L$ type and high phosphate to a soil of slightly lower $p \mathrm{H}$ to induce the $S$ type. Nuclear DNA estimations were carried out at weekly intervals on seedlings of both types and also on

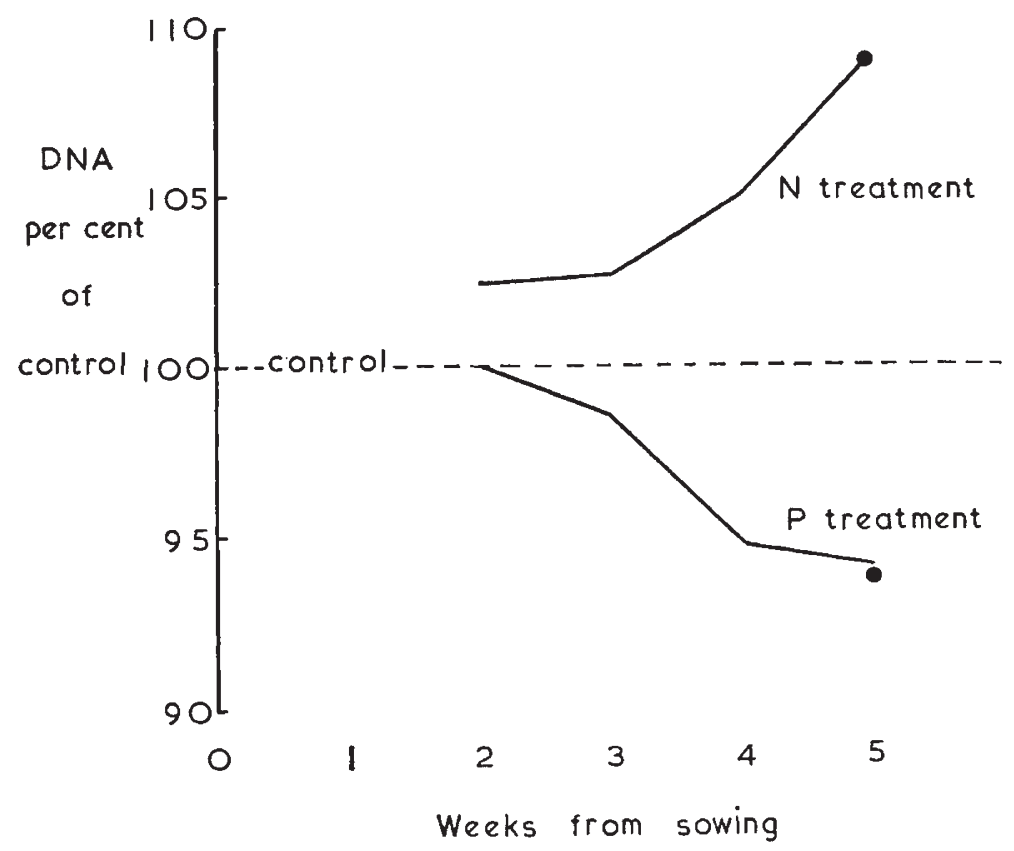

Frg. 3.-Changes in DNA in the nuclei of plastic plants grown in inducing environments during the first five weeks of growth. The two points show the percentage values of the large and small genotrophs calculated from the data in table 1 .

seedlings of the plastic genotroph used as controls grown outside in noninducing conditions. The results are given in fig. 3 , where the DNA values are represented as percentages of those of the plastic genotroph. There is a gradual divergence of DNA per nucleus in the two treatments; an increase in DNA under high nitrogen and a decrease under high phosphate conditions. These changes are in the expected direction and after 5 weeks the difference between them is practically identical to that between $L$ and $S$ given earlier. No values are given for the first week because the plastic genotroph grown outside had not emerged sufficiently for handling of the apex. Values for the nitrogen and phosphate treatments which were obtained at this stage were virtually identical. It therefore seems that as far as nuclear DNA is concerned quantitative changes occur during this initial growth period and are almost certainly completed during this period.

Nuclear DNA measurements were also carried out on the progeny of these plants grown to maturity in the $\mathrm{N}$ and $\mathrm{P}$ soil, $L$ and $S$ genotrophs being 
used as controls. The results and the analysis of variance (table 8) show quite clearly that the difference in nuclear DNA is carried through to at least the first generation. This difference is highly significant and is in fact very similar to the difference between the $L$ and $S$ genotrophs.

TABLE 8

Nuclear DNA values of $4 C$ nuclei of $\mathrm{L}$ and $\mathrm{S}$ genotrophs and of the progeny of the plastic genotroph grown under high nitrogen $(\mathcal{N})$ and high phosphate $(P)$ environment

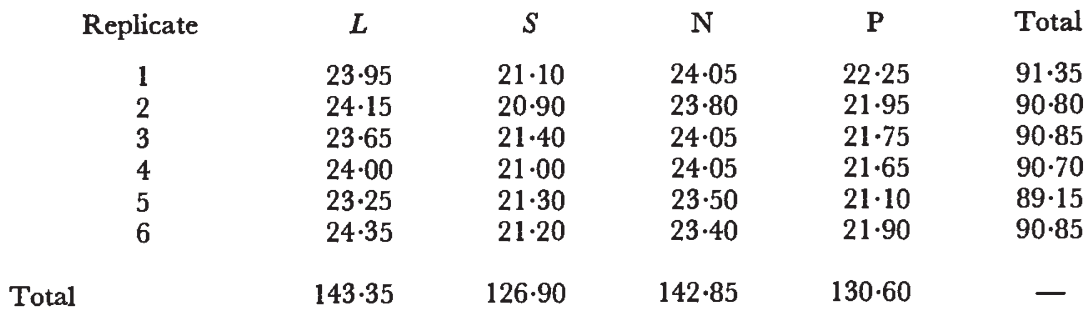

\begin{tabular}{lcccc}
\multicolumn{5}{c}{ Analysis of variance } \\
& d.f. & Mean square & Variance ratio & Probability \\
Genos & 3 & 11.830 & 13.660 & $<0.001$ \\
N-P & 1 & 12.505 & 14.440 & $<0.01$ \\
$L-S$ & 1 & 20.550 & 25.982 & $<0.001$ \\
$L+S-N+P$ & 1 & 0.427 & - & N.S. \\
Replicate & 5 & 0.142 & - & N.S. \\
Error & 15 & 0.866 & - & - \\
Total & 23 & - & - & -
\end{tabular}

TABLE 9

Analysis of variance of plant weights of $\mathrm{L}$ and $\mathrm{S}$ genotrophs and the progeny of plastic genotroph grown under high nitrogen $(\mathcal{N})$ and high phosphate $(P)$

\begin{tabular}{lcccc}
\multicolumn{1}{c}{ Item } & d.f. & Mean square & Variance ratio & Probability \\
Between Genos & 3 & 40.680 & 13.040 & $<0.001$ \\
$\quad$ N-P & 1 & 33.063 & 10.590 & $<0.01$ \\
$L-S$ & 1 & 83.266 & 26.688 & $<0.001$ \\
$\quad L+S-\mathrm{N}+\mathrm{P}$ & 1 & 5.695 & 1.825 & N.S. \\
$\quad$ Replicates & 7 & 12.700 & 4.070 & $<0.1$ \\
Error & 21 & 3.120 & - & - \\
$\quad$ Total & 31 & - & - & -
\end{tabular}

A similar comparison in plant weights was also carried out on plants grown under artificial daylight in a heated greenhouse (table 9). A difference in plant weight parallel to the difference in DNA is noted between progeny of $\mathrm{N}$ and $\mathrm{P}$ treated plants $(\mathrm{P}<0 \cdot 01)$, although this difference is not as marked. It is known from previous work (Durrant, loc. cit.) that the difference in plant weight between even the $L$ and $S$ genotrophs under greenhouse conditions is much lower than that obtained under field conditions. However, the difference in plant weight between progeny of the 
$\mathrm{N}$ and $\mathrm{P}$ treated plants is not as high as that between the $L$ and $S$ genotrophs. This seems to suggest that although the DNA difference is maintained a complete change to the $L$ and $S$ phenotype has not been attained.

\section{Stability of Nuclear DNA of the genotrophs GROWN UNDER GONTRASTING ENVIRONMENTS}

Once induced from the plastic genotroph, the large and small genotrophs have remained stable in their plant weights for many generations. To answer the question whether they are also stable in their nuclear DNA

TABLe 10

Nuclear DNA in shoot apices of $\mathrm{L}, \mathrm{S}$ and $\mathrm{Pl}$ genotrophs grown in contrasting environments

\begin{tabular}{|c|c|c|c|c|c|c|c|c|c|}
\hline \multirow{3}{*}{$\begin{array}{l}\text { Genotroph } \\
\text { Condition }\end{array}$} & \multicolumn{9}{|c|}{ Total of 4 replicates } \\
\hline & $L$ & $L$ & $L$ & $S$ & $S$ & $S$ & $P l$ & $P l$ & $P l$ \\
\hline & $\mathbf{N}$ & $\mathbf{P}$ & C & $\mathbf{N}$ & $\mathbf{P}$ & C & $\mathrm{N}$ & $\mathbf{P}$ & $\mathrm{C}$ \\
\hline DNA & $92 \cdot 50$ & $93 \cdot 07$ & $96 \cdot 65$ & $83 \cdot 65$ & $82 \cdot 60$ & $83 \cdot 00$ & $92 \cdot 10$ & 81.95 & $89 \cdot 55$ \\
\hline
\end{tabular}

Analysis of variance

\begin{tabular}{|c|c|c|c|c|}
\hline Item & d.f. & Mean square & Variance ratio & Probability \\
\hline Replicate & 3 & 0.073 & - & - \\
\hline $\begin{array}{l}\text { Treatment } \\
\text { (i) } L-S \\
\text { (ii) } L+S-P l \\
\text { (iii) } \mathrm{N}-\mathrm{P} \\
\text { (iv) } \mathrm{N}+\mathrm{P}-\mathrm{C}\end{array}$ & $\begin{array}{l}8 \\
1 \\
1 \\
1 \\
1\end{array}$ & $\begin{array}{r}7 \cdot 769 \\
45 \cdot 293 \\
0 \cdot 253 \\
4 \cdot 708 \\
2 \cdot 181\end{array}$ & $\begin{array}{r}41 \cdot 545 \\
242 \cdot 208 \\
1 \cdot 353 \\
25 \cdot 176 \\
11 \cdot 663\end{array}$ & $\begin{array}{l}<0.001 \\
<0.001 \\
\text { N.S. } \\
<0.001 \\
<0.01\end{array}$ \\
\hline $\begin{array}{l}\text { Interactions } \\
\text { (v) } L-S / \mathrm{N}-\mathrm{P} \\
\text { (vi) } L+S-P l / \mathrm{N}-\mathrm{P} \\
\text { (vii) } L-S / \mathrm{N}+\mathrm{P}-\mathrm{C} \\
\text { (viii) } L+S-P l / \mathrm{N}+\mathrm{P}-\mathrm{C}\end{array}$ & $\begin{array}{l}1 \\
1 \\
1 \\
1\end{array}$ & $\begin{array}{l}0 \cdot 164 \\
8 \cdot 184 \\
1 \cdot 327 \\
0 \cdot 048\end{array}$ & $\begin{array}{r}-\overline{43 \cdot 765} \\
7 \cdot 096 \\
-\end{array}$ & $\begin{array}{l}<\overline{0.001} \\
<0.05 \\
-\end{array}$ \\
\hline Error & 24 & $0 \cdot 187$ & - & - \\
\hline Total & 35 & - & - & - \\
\hline
\end{tabular}

content they were grown in the same $\mathrm{N}$ and $\mathrm{P}$ inducing environments already described, together with seedlings of the plastic genotroph, and nuclear DNA estimations made on shoot apices after 5 weeks growth. All three genotrophs were also grown out of doors in a non-inducing environment as control plants. Four plants of each genotroph were grown separately in pots in each environment (table 10).

The difference in nuclear DNA between $L$ and $S$ over all environmental treatments is highly significant (i), and again of the order of 16 per cent. and this difference is not altered by $\mathrm{N}$ and $\mathrm{P}(\mathrm{v})$. Further, the nuclear DNA of the plastic genotroph has diverged considerably and in the expected direction under the effects of $\mathrm{N}$ and $\mathrm{P}$ which is in marked contrast to the stability of the nuclear DNA of the $L$ and $S$ genotroph under these conditions (vi). This difference is highly significant $(P=<0.001)$ and is therefore wholly responsible for the over-all difference between $N$ and $P$ (iii), since these treatments have been shown to have no effect on $L$ and $S$. The significance 
of the higher nuclear DNA value of the $L$ genotroph grown under control conditions than in $\mathrm{N}$ and $\mathrm{P}$ (iv) is not clear at the moment and further studies are being carried out.

\section{Discussion}

There are large differences in dry mass, nuclear volume and in nuclear DNA between the genotrophs of Stormont Cirrus. Although the measurements were made on whole nuclei, the evidence indicates that changes have occurred in the chromosomes themselves since a similar difference is observed when both $4 \mathrm{G}$ interphase nuclei and well-flattened metaphase preparations are measured. This rules out the possibility of a large effect due to extra chromosomal material in the nucleus taking up the stain.

A change in the chromosomal DNA would be expected to manifest itself by changes in chromosome volume. Unfortunately, no measurements of chromosome volumes have been obtained to date owing to the difficulty in obtaining suitable well-flattened metaphase preparations. However, if there is any change in chromosome size associated with the genotrophic change it must be spread over a number of chromosomes. Flax has 15 pairs of small chromosomes of approximately equal length and since the large genotroph has about 16 per cent. more DNA than the small genotroph it follows that if the additional DNA is in one pair of chromosomes only, then one would expect in the large $\times$ small hybrid to have one chromosome much bigger than its homologue. No such feature has been observed at metaphase I of meiosis where if present it would be seen as a grossly assymetrical bivalent. In fact pairing appears to be completely normal in the $L \times S$ and $S \times L$ hybrids. However, recent cytological work on chromosome configurations in pollen mother cells of colchicine-induced autotetraploids of the $L$ and $S$ genotrophs and the cross between them has indicated that there are slight differences in homology between chromosomes of the $L$ and $S$ genotrophs. Results show that for any specific chiasma frequency there are fewer quadrivalents and more bivalents in the hybrids than in the parental p.m.c.'s. It is possible that permanent structural changes have occurred in the chromosomes during the genotrophic change which are too small to affect pairing during meiosis in the diploid "hybrids", but might lead to preferential pairing in the tetraploid hybrids between chromosomes of maternal and paternal origin.

The divergence in nuclear DNA associated with selection for low and high plant weights in the epitrophs has its counterpart in the work of Rees and Jones (1967), who found that the progeny of a backcross to one of the parents of the $F_{1}$ hybrid of two Lolium species differing in chromosome size and nuclear DNA content gave a range of DNA values and furthermore this could be correlated with the range in certain phenotypic characters.

Any statement on the nature of this nuclear change in this flax variety must be speculative at this stage in the investigations. It is conceivable that these changes in DNA are a result of changes in polynemy of whole chromosomes or part of them. Even changes in chromosome length cannot be ruled out, since if this was spread over the whole chromosome complement it would be difficult to detect at meiosis in the $F_{1}$ hybrid.

Although it is not known how these changes are brought about the evidence shows that they are induced at a specific stage of development and completed prior to gametogenesis. 


\section{Summary}

1. Nuclear changes associated with genotrophic changes in flax plants are described.

2. Feulgen photometry measurements showed significant nuclear DNA differences between large $(L)$ and small $(S)$ genotrophs of both Stormont Cirrus and Lyral Prince; the plastic $(P l)$ genotroph had an intermediate value in both cases. These differences were strongly correlated with differences in plant weight. Nuclear DNA differences between eight commercial varieties of flax were small and not significant.

3. Further experiments ruled out possible errors due to different rates of penetration of fixative or stain or to different growth rates of the genotrophs.

4. Parallel differences to the DNA values between the $L$ and $S$ genotrophs of Stormont Cirrus were obtained from both nuclear volumes and nuclear dry mass determinations.

5. A further correlation between nuclear changes and phenotype were obtained from analysis of epitrophs $\left(F_{5}\right.$ selection lines) derived from a cross between the $S$ genotroph and a white flowered mutant $\left(L^{w}\right)$ of the $L$ genotroph. Large plants had more nuclear DNA than small plants.

6. The actual change in nuclear DNA occurs during the first 5 weeks of growth.

7. The exact location of the DNA differences is not known but it is most probably chromosomal.

Acknowledgements.-I would like to thank Dr. A. Durrant and Dr. H. Rees for their help and guidance during this work.

\section{References}

BARER, R. 1952. Interference microscopy and mass determination. Nature, Lond., 169, 366. DEEley, E. M., DAVIES, H. G., AND CHAYEN, J. 1957. The DNA content of cells in roots of Vicia faba. Exptl. Cell Research, 12, 582.

DURRANT, A. 1962. The environmental induction of heritable change in Linum. Heredity, $17,27-61$.

LEUCHTENBERGeR, c. 1954. Critical evolution of Feulgen microspectrophotometry for estimating amount of DNA in cell nuclei. Science, 120, 1022.

MCLEISH, J., AND sUNDERLAND, N. 1961. Measurements of DNA in higher plants Feulgen photometry and chemical methods. Exptl. Cell Research, 24, 527-540.

MCLEISH, J. 1963. Quantitative relationship between deoxyribonucleic acid and ribonucleic acid in isolated plant nuclei. Proc. Roy. Soc. B, 158, 261-278.

REES, H., AND JoNES, G. H. 1967. Chromosome evolution in Lolium. Heredity, 22, 1-18.

RIS, H., AND MIRSKY, A. E. 1949. Quantitative cytochemical determination of deoxyribonucleic acid with the Feulgen Nucleal Reaction. 7. Gen. Physiol., 33, 125.

swIFT, H. 1955. In The Nucleic Acids, Vol. II. Eds. Chagraff, E., and Davidson, J. N. Academic Press, New York.

VENDRELY, R., AND VENDRELY, c. 1956. The results of cytophotometry in the study of deoxyribonucleic acid (DNA) content of the nucleus. Intern. Rev. Cytol., 5, 171.

walker, P. M. B. 1959. In The Cell, Vol. I. Eds. Brachet, J., and Mirsky, A. E. Academic Press, New York. 